Article

\title{
Analgesic, Anti-Inflammatory, Cytotoxic Activity Screening and UPLC-PDA-ESI-MS Metabolites Determination of Bioactive Fractions of Kleinia pendula
}

\author{
Mohammad Alfaifi ${ }^{1, *}$, Abdulrhman Alsayari ${ }^{2}$, Narasimman Gurusamy ${ }^{2}$, Justin Louis ${ }^{2}$, \\ Serag Eldin Elbehairi ${ }^{1}{ }^{1}$, Kumar Venkatesan ${ }^{2}{ }^{(0)}$, Sivakumar Annadurai ${ }^{2}$, Yahya I. Asiri ${ }^{2}$, \\ Ali Shati ${ }^{1}$, Kamel Saleh ${ }^{1}$, Helmi Alboushnak ${ }^{1}$, Heba Handoussa ${ }^{3}$, Abdullatif Bin Muhsinah ${ }^{2}$ (D) \\ and Amira Abdel Motaal ${ }^{2}$ \\ 1 Department of Biology, Faculty of Science, King Khalid University, Abha 9004, Saudi Arabia; \\ serag@kku.edu.sa (S.E.E.); aaalshati@kku.edu.sa (A.S.); kasaleh@kku.edu.sa (K.S.); \\ halboushnak@kku.edu.sa (H.A.) \\ 2 College of Pharmacy, King Khalid University, Abha 9004, Saudi Arabia; alsayari@kku.edu.sa (A.A.); \\ gurunaras@gmail.com (N.G.); justin48@gmail.com (J.L.); kumarve@kku.edu.sa (K.V.); \\ sannadurai@kku.edu.sa (S.A.); yialmuawad@kku.edu.sa (Y.I.A.); ajmohsnah@kku.edu.sa (A.B.M.); \\ aabdulmtaal@kku.edu.sa (A.A.M.) \\ 3 Department of Pharmaceutical Biology, Faculty of Pharmacy and Biotechnology, German University in \\ Cairo, Cairo 11835, Egypt; heba.handoussa@guc.edu.eg \\ * Correspondence: alfaifi@kku.edu.sa
}

Received: 11 December 2019; Accepted: 17 January 2020; Published: 20 January 2020

\begin{abstract}
Kleinia pendula (Forssk.) DC. is a prostrate or pendent dark green succulent herb found in the southwestern mountain regions of Saudi Arabia. The literature survey of the plant reveals a lack of phytochemical and pharmacological studies, although traditional uses have been noted. The objective of the present work was to assess the in vivo analgesic and anti-inflammatory activities, as well as, the in vitro cytotoxic potential of the fractions of Kleinia pendula, and correlate these activities to the plant metabolites. The methanolic extract of Kleinia pendula was subjected to fractionation with $n$-hexane, ethyl acetate, chloroform, $n$-butanol, and water. The fractions were screened for their analgesic and anti-inflammatory activities, as well as cytotoxic activity against breast, liver, and colon cancer cell lines. The $n$-hexane and chloroform fractions of Kleinia pendula showed significant cytotoxic activity against all three cancer cell lines tested. The ethyl acetate and chloroform fractions showed significant analgesic and anti-inflammatory activities. The metabolites in these three active fractions were determined using UPLC-PDA-ESI-MS. Thus, the analgesic and anti-inflammatory activities of the plant were attributed to its phenolic acids (caffeoylquinic acid derivatives, protocatechuic, and chlorogenic acids). While fatty acids and triterpenoids such as (tormentic acid) in the hexane fraction are responsible for the cytotoxic activity; thus, these fractions of Kleinia pendula may be a novel source for the development of new plant-based analgesic, anti-inflammatory, and anticancer drugs.
\end{abstract}

Keywords: Kleinia pendula (Forssk.) DC.; fraction; metabolite; cytotoxic; analgesic; anti-inflammatory

\section{Introduction}

Historically, natural products derived from plants and animals have been the source of virtually all medicinal preparations. Natural products or direct derivatives of natural products have contributed to $49 \%$ of cancer medications approved by the U.S. Food and Drug Administration (FDA) between 1981 
and 2014 [1]. Natural product collections exhibit certain advantages over their synthetic counterparts. They exhibit a high degree of stereochemistry and a wide range of pharmacophores. Since they are natural metabolites, natural products possess the unique property of metabolite-likeness. This property renders them as likely substrates of transporter systems, which ensure their delivery to intracellular sites of action [2]. The genus Kleinia is a flowering plant comprised of 40 species that are distributed throughout Somalia, the Middle East, Madagascar, and India [3,4]. Three species of this genus are commonly found in the southern regions of Saudi Arabia: K. odora (Forssk) DC, K. deflersii (O. Schwartz), and K. pendula (Forssk.) Sch. Bip [5-7]. Several species of Kleinia are known to be rich sources of oxygenated sesquiterpenoids, such as germacrane, oplopane abrotanifolon derivatives, and lupane-type tri-terpenoids [8-11]. The plant of interest, Kleinia pendula (Forssk.) DC., (Figure 1) has been used in Saudi and Yemeni traditional medicine to treat otitis (inflammation of the ear) [12]. The decoction of the fresh succulent Kleinia pendula has been used to treat swollen body parts in Ethiopian traditional medicine [13]. In the southern part of Somalia, the finely chopped aerial parts of the Kleinia pendula have been used as an insectifuge and/or insecticide in traditional and local veterinary practice.

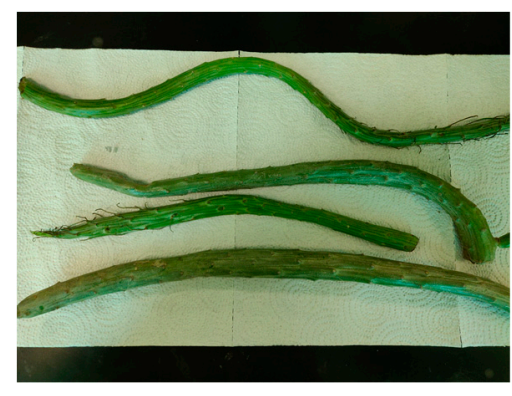

Figure 1. Kleinia pendula.

The only report on phytochemical investigations on this plant pertains to the isolation and characterization of biologically active sesquiterpene alcohol, $4 \alpha \mathrm{H}$-eudesm- $5 \alpha$-ol, from the steam volatile oil of the aerial parts of Kleinia pendula [14]. The in vitro anticancer, antimicrobial, antioxidant, antiplasmoidal, antileishmanial, and antitrypanosomal activities of the methanol and aqueous extracts of selected medicinal plants, including Kleinia pendula, have been reported [3,12]. The lack of extensive phytochemical and pharmacological studies on this plant prompted the present study. In this work, the analgesic and anti-inflammatory potential of the fractions of Kleinia pendula on animal models have been demonstrated for the first time. Additionally, cytotoxic activity screening of the fractions against three human cancer cell lines has been reported. The phytochemical characterization of the bioactive fractions was carried out using an Ultra Performance Liquid Chromatography-Photodiode Array-Electrospray Ionization-Mass spectrometry (UPLC-PDA-ESI-MS) method.

\section{Results}

\subsection{Acute Oral Toxicity Studies}

The n-hexane, chloroform and ethyl acetate fractions of Kleinia pendula were subjected to an acute oral toxicity study at the dose of $2000 \mathrm{mg} / \mathrm{kg}$ body weight in female mice, as per the Organization for Economic Co-operation and Development (OECD) 420 guidelines. Gross behavioral parameters were closely observed for the first $3 \mathrm{~h}$ then at an interval of every $4 \mathrm{~h}$ during the next $48 \mathrm{~h}$, such as mortality, diarrhea, respiratory problems, Straub tail, piloerection, convulsions were carefully examined in each animal. Treatment with the fractions of Kleinia pendula did not produce any mortality at a dose of $2000 \mathrm{mg} / \mathrm{kg}$ (p.o.), and there were no changes in the gross behavior of the animals. Moreover, the animals were kept under observation for two weeks after testing. Food and water intake had no significant difference among the groups studied. 


\subsection{Analgesic Activity of Fractions of Kleinia pendula}

Chloroform, ethyl acetate, and $n$-hexane fractions were individually screened for analgesic activity. The doses were determined based on acute oral toxicity studies. The mice were administered with 100 , 200, and $300 \mathrm{mg} / \mathrm{kg}$ fractions of Kleinia pendula followed by the measurement of analgesic activities using Eddy's hot plate method at 0, 30, 60, and 120 min after the drug administration. As shown in Figure 2, the chloroform, ethyl acetate, and $n$-hexane fractions of Kleinia pendula exhibited a significant increase in analgesic activity at $30 \mathrm{~min}$, comparable to the effect of the standard drug diclofenac sodium $(10 \mathrm{mg} / \mathrm{kg})$.

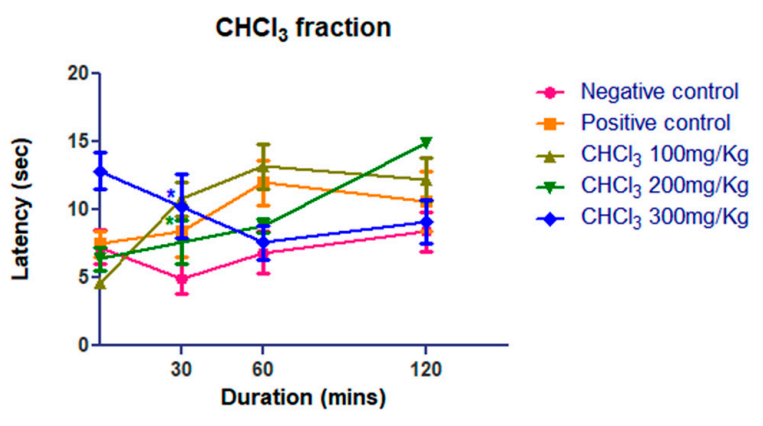

A

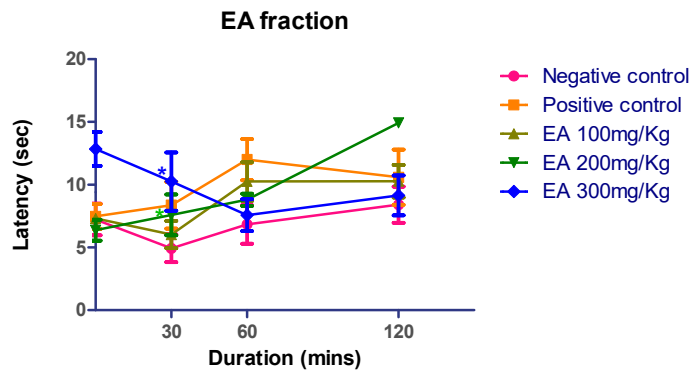

B

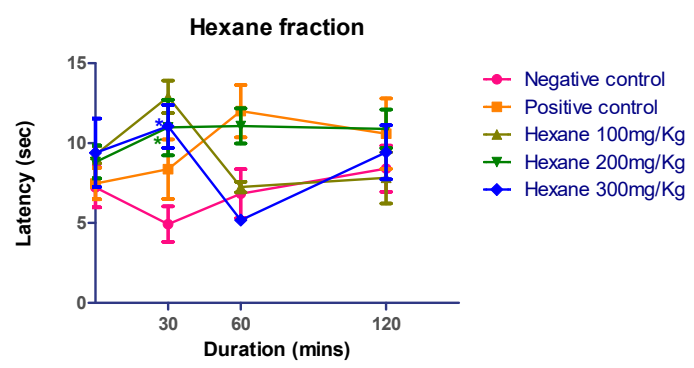

C

Figure 2. Analgesic activity of various fractions of Kleinia pendula at different doses and time points. The $\left(\mathrm{CHCl}_{3}\right)$ fraction at doses of 100,200 , and $300 \mathrm{mg} / \mathrm{kg}$ body weight of the animal (A) exhibited analgesic activity. Ethyl acetate (EA) fraction at doses of 100, 200, and $300 \mathrm{mg} / \mathrm{kg}$ body weight of the animal (B) exhibited analgesic activity. The hexane fraction at doses of 100, 200, and $300 \mathrm{mg} / \mathrm{kg}$ body weight of the animal (C) exhibited low analgesic activity. Diclofenac sodium $(10 \mathrm{mg} / \mathrm{kg})$ was used as a positive control, and standard saline was used as negative control. The values are represented as mean \pm SEM. Statistical analysis was done using one-way analysis of variance using the Dunnett's posthoc test. 


\subsection{Anti-Inflammatory Activity of Fractions of Kleinia Pendula}

The animals treated with standard saline showed a progressively increased inflammation at 60, 120, and $180 \mathrm{~min}$. The chloroform and ethyl acetate fractions of Kleinia pendula were screened for anti-inflammatory activity.

The mice were administered with 100, 200, and $300 \mathrm{mg} / \mathrm{kg}$ fractions of Kleinia pendula. The volume of paw edema was recorded using a plethysmometer at $0,60,120$, and 180 min after the drug administration. The chloroform and the ethyl acetate fractions at (200 and $300 \mathrm{mg} / \mathrm{kg}$ ) of Kleinia pendula significantly reduced the paw edema at $180 \mathrm{~min}$, and these results were comparable to the effect of the standard drug diclofenac sodium (10 mg/kg) used in this study (Figure 3 ).

\section{$\mathrm{CHCl}_{3}$ fraction}

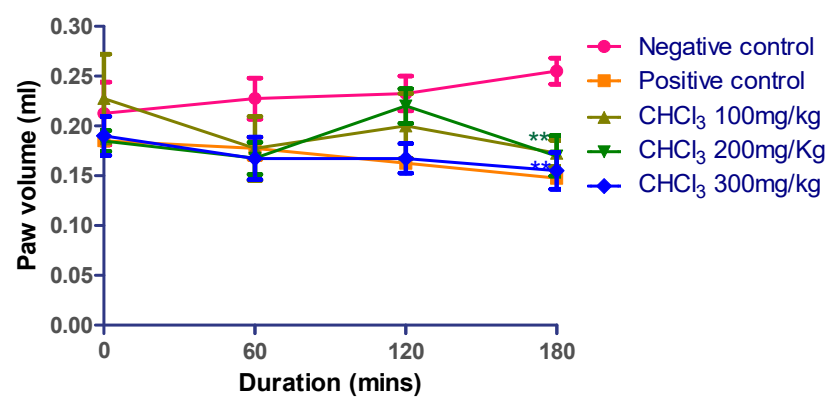

A

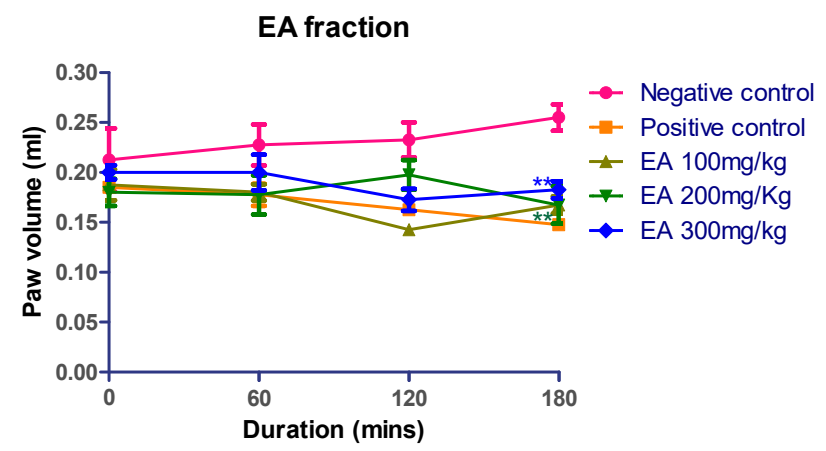

B

Figure 3. Anti-inflammatory activity of various fractions of Kleinia pendula. (A) Anti-inflammatory activity of various fractions of Kleinia pendula at different doses and time points. Chloroform $\left(\mathrm{CHCl}_{3}\right)$ fraction at doses of 100, 200 and $300 \mathrm{mg} / \mathrm{Kg}$ body weight of the animal exhibited anti-inflammatory activity. (B) Ethyl acetate (EA) fraction at doses of 100, 200 and $300 \mathrm{mg} / \mathrm{kg}$ body weight of the animal exhibited anti-inflammatory activity. Diclofenac sodium $(10 \mathrm{mg} / \mathrm{kg})$ was used as a positive control, and standard saline was used as negative control. The values are represented as Mean \pm SEM. Statistical analysis was done using one-way analysis of variance using Dunnett's posthoc test.

\subsection{Cytotoxic Assay}

The cytotoxic profile of the methanolic extract and the fractions of Kleinia pendula were tested against breast cancer (MCF-7), liver cancer (HepG2), and colon cancer (HCT-116) cell lines. The methanolic extract, hexane and chloroform fractions of Kleinia pendula showed a more potent cytotoxic profile against all three cancer cell lines tested (Table 1 ). The $\mathrm{IC}_{50}$ values of the hexane and chloroform fractions of Kleinia pendula were comparable to the $\mathrm{IC}_{50}$ values of the standard drug doxorubicin. Whereas the ethyl acetate, butanol, and water fractions of Kleinia pendula showed a weaker cytotoxic profile against 
all three cancer cell lines tested. Importantly, the hexane fraction demonstrated a high cytotoxic effect against all three cancer cells tested, with $\mathrm{IC}_{50}$ values ranging from $0.07 \mu \mathrm{g}$ to $0.19 \mu \mathrm{g}$.

Table 1. Cytotoxic activities of extract/fractions of Kleinia pendula against different cancer cell lines.

\begin{tabular}{cccc}
\hline \multirow{2}{*}{ Fractions/Extract } & \multicolumn{3}{c}{ IC $_{\mathbf{5 0}}(\boldsymbol{\mu g} / \mathrm{mL})$} \\
\cline { 2 - 4 } & $\mathbf{M C F}-\mathbf{7}(\mu \mathrm{g})$ & HepG2 $(\mu \mathrm{g})$ & HCT-116 $(\mu \mathrm{g})$ \\
\hline Methanol extract & $3.2 \pm 0.6$ & $3.17 \pm 0.69$ & $4.8 \pm 0.6$ \\
\hline Hexane fraction & $0.07 \pm 0.03$ & $0.19 \pm 0.02$ & $0.11 \pm 0.01$ \\
\hline Chloroform fraction & $0.13 \pm 0.07$ & $0.24 \pm 0.03$ & $0.19 \pm 0.15$ \\
\hline Ethyl acetate fraction & $90.22 \pm 18.6$ & $\geq 100$ & $28.1 \pm 5.3$ \\
\hline Butanol fraction & $\geq 100$ & $\geq 100$ & $\geq 100$ \\
\hline Water fraction & $\geq 100$ & $\geq 100$ & $\geq 100$ \\
\hline Doxorubicin & $0.014 \pm 0.008$ & $0.0065 \pm 0.005$ & $0.013 \pm 0.0005$ \\
\hline
\end{tabular}

$p$ values less than 0.05 are considered statistically significant. $\mathrm{IC}_{50}$ values of the fractions were significantly higher than that of positive control (Doxorubicin).

\subsection{Characterization of Metabolites from the Bioactive Fractions Using UPLC-PDA-ESI-MS}

A UPLC-PDA-ESI-MS was used to characterize metabolites (Tables 2-4) in the bioactive ethyl acetate, chloroform, and $n$-hexane fractions (Figures 4-6, respectively). Metabolite profiling revealed the presence of several compounds that belong to several classes of compounds to confirm the richness of Kleinia pendula with active metabolites. Polyol acids, phenolic acids, flavanoidal glycosides and tannins were found in the ethyl acetate and chloroform fractions. Hexane fraction revealed the presence of phenolic acids, diterpene glycosides, triterpenoids and fatty acids.

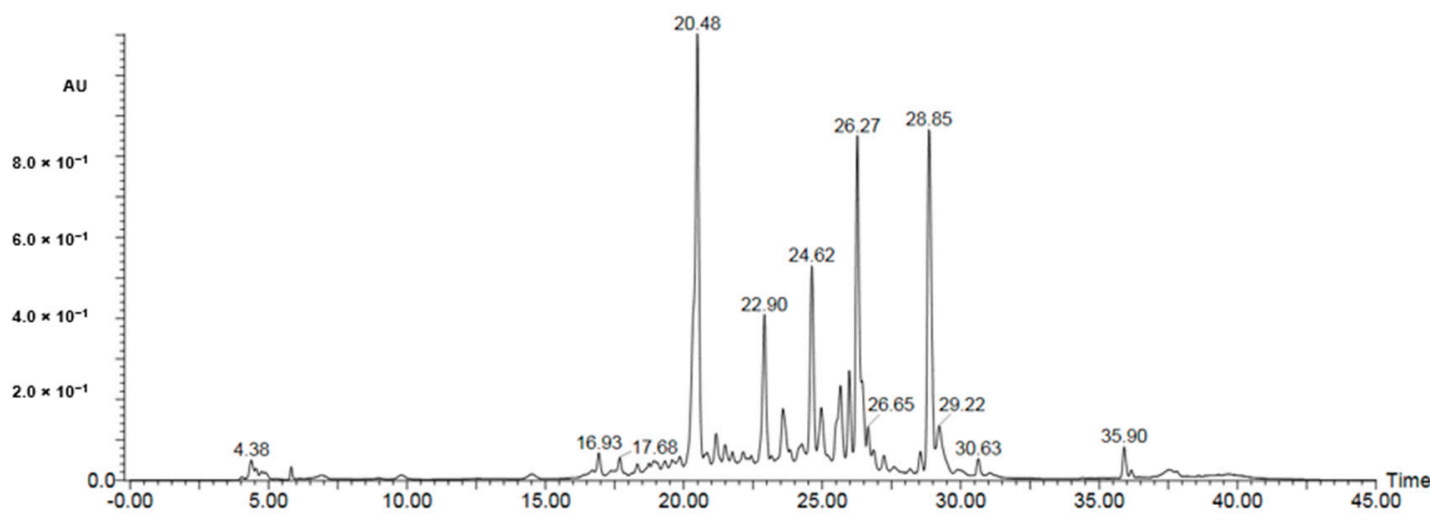

Figure 4. UPLC-PDA-ESI-MS in the bioactive ethyl acetate fractions. 
Table 2. Peak assignment using UPLC-PDA-ESI-MS of metabolites detected in ethyl acetate fraction (negative mode).

\begin{tabular}{|c|c|c|c|c|c|c|c|}
\hline Peak & $\begin{array}{l}\text { Retention } \\
\text { Time }\end{array}$ & Identified Compd. & $\begin{array}{l}\text { UV-Vis } \\
(\lambda \text { Max) }\end{array}$ & $\begin{array}{l}{[\mathbf{M}-\mathbf{H}]^{-}} \\
\quad(m / z)\end{array}$ & $\begin{array}{l}\text { Fragment } \\
\text { Ions }(m / z)\end{array}$ & $\begin{array}{l}\text { Percentage } \\
(\%)\end{array}$ & Ref. \\
\hline$K p 1$ & 4.2 & Quinic acid & 323 & 191 & $\begin{array}{c}178,173,148 \\
110\end{array}$ & 0.8 & [15]. \\
\hline$K p 2$ & 6.2 & Protocatechuic acid & 320 & 153 & 113,105 & 0.5 & [16]. \\
\hline Kp3 & 20.48 & Di-caffeoyl quinic acid & 246,310 & 515 & 191 & 5.7 & $\begin{array}{l}{[15,} \\
17]\end{array}$ \\
\hline$K p 4$ & 21.32 & Chlorogenic acid & 246,310 & 353 & 191 & 1.21 & {$[17]$} \\
\hline Kp5 & 21.98 & Feruloyl-quinic acid & 247,310 & 367 & 191 & 0.62 & {$[15]$} \\
\hline Kp6 & 22.9 & $\begin{array}{l}\text { Isorhamnetin-3-O- } \\
\text { glucoside-7-O- } \\
\text { rhamnoside }\end{array}$ & 230,262 & 623 & 315,153 & 3.2 & [18] \\
\hline$K p 7$ & 23.09 & Feruloyl-quinic acid & 247,310 & 367 & 191 & 1.32 & {$[15]$} \\
\hline Kp8 & 24.6 & $\begin{array}{l}\text { Trihydroxyphenethyl-O- } \\
\text { rhamnopyranosyl-(1-6)- } \\
\text { 4-O-caffeoyl- } \\
\text { glucopyranoside }\end{array}$ & 232,282 & 621 & 487,469 & 3.4 & [19] \\
\hline$K p 9$ & 25.72 & Sinapic acid hexoside & 310 & 385 & 223 & 4.82 & {$[20]$} \\
\hline Kp10 & 25.85 & $\begin{array}{l}\text { Di-caffeoyl-hexuronide } \\
\text { derivative }\end{array}$ & 328 & 710 & $355,135,113$ & 2.5 & {$[21]$} \\
\hline Kp11 & 26.27 & Chlorogenic acid & 246,310 & 353 & 191 & 4.95 & {$[17]$} \\
\hline Kp12 & 28.86 & Feruloyl-quinic acid & 333 & 367 & 191 & 5.1 & {$[15]$} \\
\hline Kp13 & 29.22 & $\begin{array}{l}\text { Sulphate conjugate of } \\
\text { dimethyl gallic acid }\end{array}$ & 260 & 277 & 197,163 & 1.6 & $\begin{array}{l}{[22,} \\
23]\end{array}$ \\
\hline Kp14 & 30.62 & $\begin{array}{c}\text { Di-methylgallic acid } \\
\text { derivative }\end{array}$ & 267 & 291 & 155 & 0.7 & $\begin{array}{l}{[22,} \\
23]\end{array}$ \\
\hline Kp15 & 35.9 & Coumaroyl-shikimic acid & 225 & 319 & 155 & 0.92 & {$[15]$} \\
\hline Kp16 & 38.9 & $\begin{array}{l}\text { Apigenin-6,8-di- } \\
\text { C-glucoside }\end{array}$ & 246,310 & 593 & 297,135 & 1.6 & $\begin{array}{l}{[22,} \\
23]\end{array}$ \\
\hline Kp17 & 40.21 & Formylipolamiidic acid & Undetected & 419 & $401,257,155$ & 0.9 & $\begin{array}{l}{[22,} \\
23]\end{array}$ \\
\hline Kp18 & 42.82 & Procyanidin B3 & 330 & 579 & 453,127 & 0.5 & $\begin{array}{l}{[24,} \\
25]\end{array}$ \\
\hline
\end{tabular}

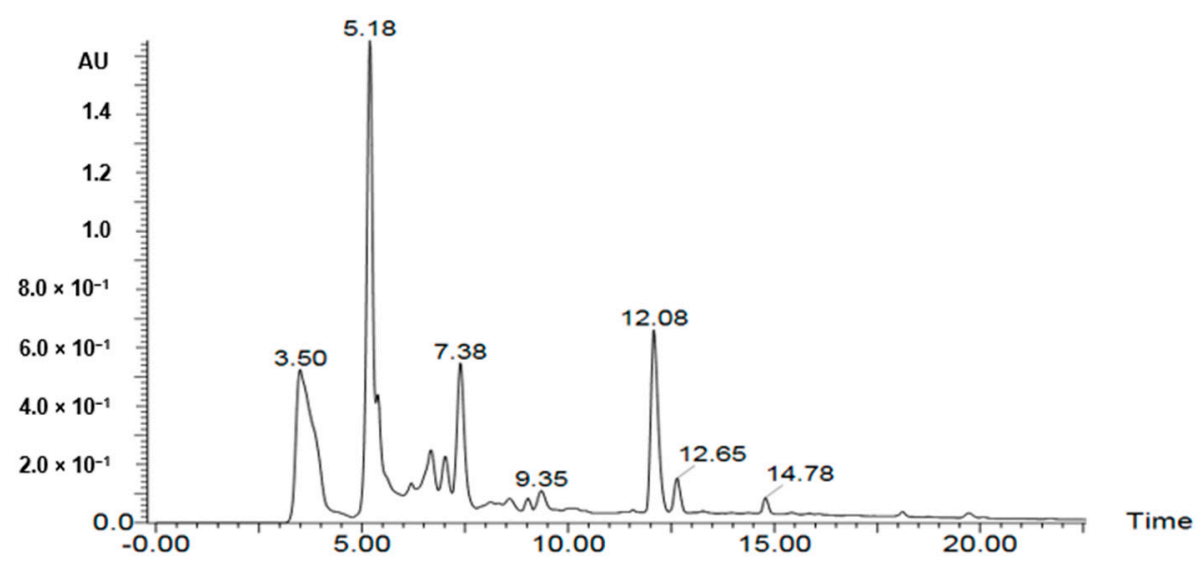

Figure 5. UPLC-PDA-ESI-MS in the chloroform fractions. 
Table 3. Peak assignment using UPLC-PDA-ESI-MS of metabolites detected in the chloroform fraction (negative mode).

\begin{tabular}{|c|c|c|c|c|c|c|c|}
\hline Peak & $\begin{array}{l}\text { Retention } \\
\text { Time }\end{array}$ & Identified Compd. & $\begin{array}{l}\text { UV-Vis } \\
(\lambda \text { Max) }\end{array}$ & $\begin{array}{c}{[\mathbf{M}-\mathbf{H}]^{-}} \\
\quad(m / z)\end{array}$ & $\begin{array}{l}\text { Fragment } \\
\text { Ions }(m / z)\end{array}$ & $\begin{array}{l}\text { Percentage } \\
(\%)\end{array}$ & Ref. \\
\hline Kp19 & 3.5 & $\begin{array}{l}\text { Hexahydroxydiphenoyl } \\
\text { (HHDP)-galloylglucose }\end{array}$ & 274 & 633 & $301,257,229$ & 5.4 & [26] \\
\hline Кр20 & 5.18 & $\begin{array}{l}\text { Dihydroxy-4-methoxyl } \\
\text { isoflavan }\end{array}$ & 226,284 & 271 & 227,135 & 3.75 & [27] \\
\hline Kp21 & 5.2 & Gallocatechin & 274 & 305 & 179 & 1.29 & [17] \\
\hline Kp22 & 6.2 & HHDP-galloylglucose & 274 & 633 & $301,257,229$ & 1.3 & [26] \\
\hline Kp23 & 6.9 & $\begin{array}{c}\text { Trihydroxyphenethyl-O- } \\
\text { rhamnopyranosyl-(1-6)- } \\
\text { 4-O-caffeoyl- } \\
\text { glucopyranoside }\end{array}$ & 232,282 & 621 & 487,469 & 3.4 & [19] \\
\hline Kp24 & 7.38 & unidentified & 230,290 & 604 & $582,462,342$ & 2.38 & [28] \\
\hline Kp25 & 9.2 & Methylretusin & 230,283 & 297 & 281,239 & 0.18 & [27] \\
\hline Kp26 & 9.35 & $\begin{array}{l}\text { Acyl-feruloyl-4-O- } \\
\text { caffeoyl-quinic acid }\end{array}$ & 220,232 & 571 & 277,191 & 0.95 & [15] \\
\hline Kp27 & 12.08 & $\begin{array}{c}\text { Glycycoumarin } \\
\text { hydroxylate glucuronide }\end{array}$ & 258 & 559 & 338 & 3.29 & $\begin{array}{l}{[22,} \\
23]\end{array}$ \\
\hline Kp28 & 12.65 & $\begin{array}{l}\text { Sulfate conjugate of } \\
\text { glycycoumarin }\end{array}$ & 283 & 447 & 367 & 2.01 & $\begin{array}{l}{[22,} \\
23]\end{array}$ \\
\hline Кр29 & 14.78 & $\begin{array}{c}\text { trisgalloyl } \\
\text { (hexahydroxydiphenoyl) } \\
\text { glucose derivative }\end{array}$ & 275 & 907 & 765,191 & 0.72 & [29] \\
\hline
\end{tabular}

Table 4. Peak assignment using UPLC-PDA-ESI-MS of metabolites detected in hexane fraction (negative mode).

\begin{tabular}{ccccccc}
\hline Peak & $\begin{array}{c}\text { Retention } \\
\text { Time }\end{array}$ & Identified Compd. & $\begin{array}{c}{[\mathbf{M}-\mathbf{H}]^{-}} \\
(\mathbf{m} / \mathbf{z})\end{array}$ & $\begin{array}{c}\text { Fragment } \\
\text { Ions }(\mathbf{m} / \mathbf{z})\end{array}$ & $\begin{array}{c}\text { Percentage } \\
(\%)\end{array}$ & Ref. \\
\hline Kp30 & 4.2 & Tinosposinenside B & 581 & $379,343,297$ & 0.21 & {$[30]$} \\
\hline Kp31 & 4.93 & Amritoside A & 555 & 537,513 & 0.42 & {$[30]$} \\
\hline Kp32 & 4.95 & Isocryptotanshinone II & 297 & 225,211 & 0.8 & {$[31]$} \\
\hline Kp33 & 5.23 & Linolenic acid & 277 & 250,219 & 3.5 & {$[31]$} \\
\hline Kp34 & 11.3 & $\begin{array}{c}\text { Octadecadienoic acid } \\
\text { derivative }\end{array}$ & 265 & 249,179 & 0.2 & {$[31]$} \\
\hline Kp35 & 14.2 & Tanshinone IIB & 311 & 275,250 & 0.73 & {$[32]$} \\
\hline Kp36 & 25.6 & Salvianolic acid G & 339 & 277,249 & 0.35 & {$[33]$} \\
\hline Kp37 & 27.97 & Tinocrisposide & 535 & 521,355 & 1.9 & {$[30]$} \\
\hline Kp38 & 31.43 & Tormentic acid & 487 & 469 & 4.9 & {$[34]$} \\
\hline Kp39 & 34.3 & 6,7-Dehydroroyleanone & 315 & 297,216 & 1.87 & {$[35]$} \\
\hline Kp40 & 36.8 & Salvianolic acid D & 417 & $197,175,135$ & 1.2 & {$[31]$} \\
\hline Kp41 & 37.80 & $\begin{array}{c}\text { Dehydrated derivative } \\
\text { of Tinosposinenside B }\end{array}$ & 419 & 297 & 3.75 & {$[30]$} \\
\hline Kp42 & 38.45 & 5-Hydroxydavisiosidec & 513 & 197 & 4.89 & {$[36]$} \\
\hline Kp43 & 39.5 & Citrostadienyl & 432 & 419 & 4.3 & {$[37]$} \\
\hline$K p 44$ & 40.58 & Unidentified & 319 & $305,291,277$ & 6.75 & n.d. \\
\hline
\end{tabular}




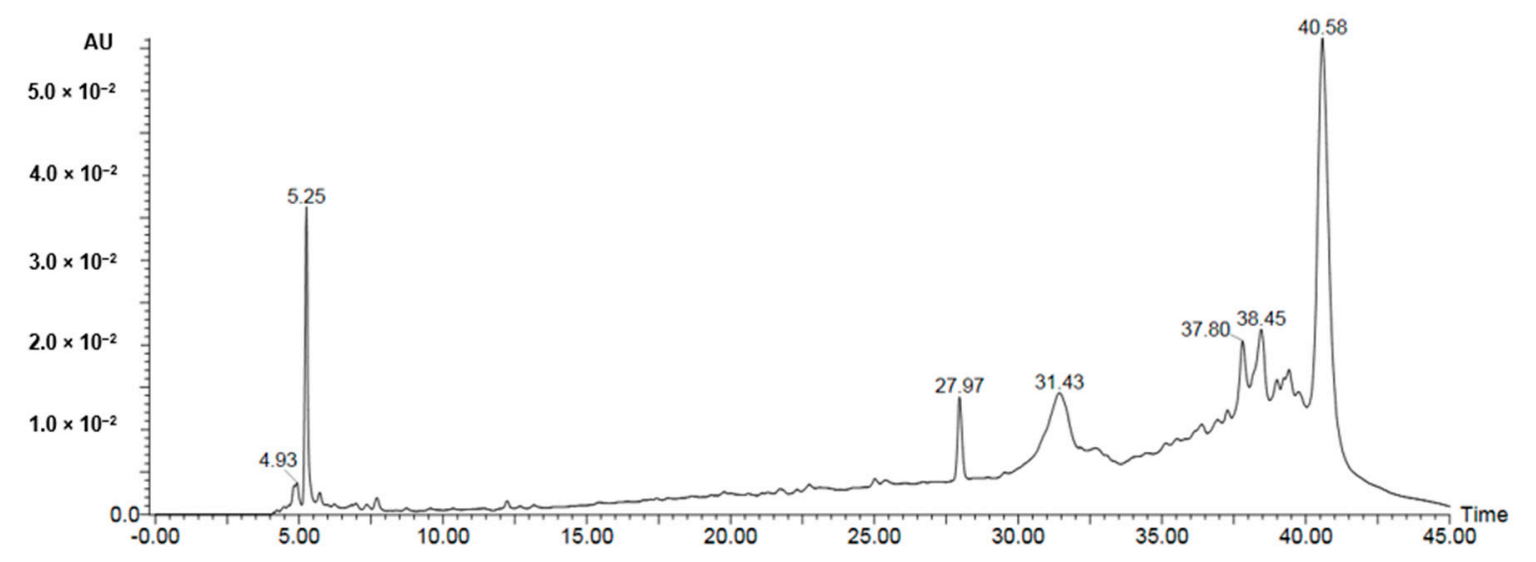

Figure 6. UPLC-PDA-ESI-MS in $n$-hexane fractions.

\section{Discussion}

This study demonstrates the in vivo analgesic and anti-inflammatory potential of the solvent fractions of Kleinia pendula for the first time. The hexane fraction of Kleinia pendula showed the most potent cytotoxic effect against three cancer cell lines (MCF7, HepG2 7 HCT-116).

The oral acute toxicity studies with fractions of Kleinia pendula at the dose of $2000 \mathrm{mg} / \mathrm{kg}$ did not produce any mortality, and no physical or behavioral changes were observed in the experimental animals during the study period. These results indicated that the estimated $\mathrm{LD}_{50}$ value of all the tested fractions was above $2000 \mathrm{mg} / \mathrm{kg}$.

The aversive effect of the thermal stimulus from Eddy's hot plate test was demonstrated by the subject mice licking their paws. This hot plate method demonstrates central nociceptive reactivity, rather than a simple reflex reaction [38]. In this study, the average latency period was increased when the ethyl acetate, chloroform, and the $n$-hexane fractions of Kleinia pendula were administered. The results demonstrated the analgesic effect of the various fractions of Kleinia pendula, probably due to the central mechanisms. Medicinal plants used as analgesics such as Tamarindus indica and Curucuma zedoaria have been shown to increase the average latency period $[39,40]$.

In the study for anti-inflammatory activity, acute inflammation was induced in the sub-plantar region using carrageenan [41]. The initial phase of the inflammation (approximately 0-1.5 h) is ascribed to the release of histamine and serotonin. The second phase $(1.5-2.5 \mathrm{~h})$ is mainly mediated by bradykinin and the third phase (beyond $2.5 \mathrm{~h}$ ) by the overproduction of the prostaglandins, leukotrienes [38]. The results showed that the chloroform fraction at a dose of $100 \mathrm{mg} / \mathrm{kg}$ effectively inhibited inflammation. Thus, the anti-inflammatory activity of the chloroform fraction of Kleinia pendula could be coupled with the inhibition of the release and the biosynthesis of histamine, serotonin, and leukotrienes. These fractions may have an antagonistic potential towards histamine and serotonin receptors, reflecting the initial phase of inflammation. Kleinia pendula has been used in Saudi and Yemeni traditional medicine to treat inflammation of the ear (Otitis) [14]. The decoction of the fresh succulent Kleinia pendula has been used to treat swollen body parts in Ethiopian traditional medicine [13]. Recently, the in vitro anti-inflammatory potential of a member of the genus Kleinia (Kleinia odora) has been reported [42]. Moreover, the methanolic extract of Kleinia pendula is reported to contain flavonoids and terpenoids [3]. The bioactive ethyl acetate, chloroform fractions were subjected to UPLC-PDA-ESI-MS metabolite screening. The major metabolites identified in the ethyl acetate fractions include Dicaffeoyl quinic acid [21], feruloyl-qunic acid [15], chlorogenic acid [17], sinapic acid hexoside [20], trihydroxyphenethyl-O-rhamnopyranosyl-(1,6)-4-O-caffeoyl-glucopyranoside [19], isorhamnetin-3-O-glucoside-7-O-rhamnoside [18], apigenin-6,8-di-C-glucoside and chlorogenic acid. The major metabolites identified in the chloroform fraction include HHDP-galloylglucose [26], dihydroxy-4-methoxylisoflavan [27], trihydroxyphenethyl-O-rhamnopyranosyl-(1-6)-4-O-caffeoyl- 
glucopyranoside [19], Glycycoumarin hydroxylate glucuronide [22,23] and sulfate conjugate of glycycoumarin $[22,23]$.

The observed anti-inflammatory activity could be attributed to the presence of caffeoyl-quinic acid derivatives [43], protocatechuic [44], and chlorogenic [45] acids in the chloroform and ethyl acetate fractions respectively. Additional studies with isolated compounds are needed to corroborate this.

Chronic inflammation may increase the risk for various cancers. This is supported by epidemiological evidence that shows anti-inflammatory agents can be used for the prevention and treatment of cancer [46]). In this study, the methanolic extract, hexane, and chloroform fractions of Kleinia pendula showed potent cytotoxicity against breast cancer (MCF-7), liver cancer (HepG2), and colon cancer (HCT-116) cell lines, although the mechanisms are currently unclear. Significantly, the hexane fraction showed the most potent cytotoxic effect against all the cancer cell lines tested. The UPLC-PDA-ESI-MS metabolite screening of bioactive hexane fraction revealed the presence of major metabolites including tormentic acid [34], 5-hydroxyadvisiosidec [36], citrostadienyl [37], dehydrated derivative of tinosposinenside B [30] and tinocrisposide [30]. The observed cytotoxic activity could be attributed to the presence of fatty acids and triterpenoid (tormentic acid [47]) in the hexane fraction. Additional studies with isolated compounds are needed to corroborate this. This is in contrast to the earlier report where the methanolic and aqueous extract of Kleinia pendula was reported to have no significant cytotoxic activity against human urinary bladder cancer cell lines (5637) and breast cancer cell lines (MCF-7) [3].

\section{Materials and Methods}

\subsection{Plant Material}

Fresh parts of Kleinia pendula were collected during January 2017 from the Faifa Mountains in the southwest region of Saudi Arabia. Kleinia pendula is an annual or perennial herb, pendulous, succulent, leafless, stem cylindrical, branched. Leaves reduced to subulate scales upto $1.5 \mathrm{~cm}$ long, these arising from wart-like outgrowths on stems. Individual stems are joined and brittle, $20-30 \mathrm{~cm}$ long and 1.5 to $2 \mathrm{~cm}$ in diameter. The plant material was identified by a botanist in the Biology Department, College of Science, King Khalid University, and prepared for extraction.

\subsection{Preparation of Extract and Fractions}

The fresh aerial parts of $K$. pendula $(4 \mathrm{~kg})$ were pulverized and extracted by maceration with methanol $(4 \times 3 \mathrm{~L})$ at room temperature. The methanolic extract was filtered and evaporated at a temperature of $40{ }^{\circ} \mathrm{C}$ using a rotary evaporator. The dried methanolic extract $(200 \mathrm{~g}, 5 \%)$ was subsequently re-dissolved in water $(300 \mathrm{~mL})$ and partitioned successively several times with $\mathrm{n}$-hexane $(3 \times 300 \mathrm{~mL})$, chloroform $(3 \times 300 \mathrm{~mL})$, ethyl acetate $(3 \times 300 \mathrm{~mL})$, and $n$-butanol $(3 \times 300 \mathrm{~mL})$ to provide the corresponding fractions. The fractions were evaporated using a rotary evaporator under reduced pressure at $40{ }^{\circ} \mathrm{C}$ to yield fractions of $n$-hexane $(14 \mathrm{~g}, 7 \%)$, chloroform $(8 \mathrm{~g}, 4 \%)$, ethyl acetate $(20 \mathrm{~g}, 10 \%)$ and $n$-butanol ( $35 \mathrm{~g}, 17.5 \%)$ and the remainder of the aqueous fraction $(95 \mathrm{~g}, 17.5 \%)$. The dried fractions were stored at $-20{ }^{\circ} \mathrm{C}$ until used for screening of analgesic, anti-inflammatory, and cytotoxic activities.

\subsection{Animals}

All experiments were performed on Swiss mice of both sexes weighing between $20 \mathrm{~g}$ to $25 \mathrm{~g}$. The animals were maintained on a $12 \mathrm{~h}$ light/dark cycle, with water and food ad libitum until use. This study was carried out according to the Ethics Committee, King Khalid University, Abha, Kingdom of Saudi Arabia, and followed the recommendations of the National Institutes of Health Guide for Care and Use of Laboratory Animals (Publication No. 85-23, revised 1985). 


\subsection{Acute Toxicity Studies}

Acute toxicity studies of the $n$-hexane, chloroform and ethyl acetate fractions of Kleinia pendula were carried out at a dose of $2000 \mathrm{mg} / \mathrm{kg}$ in female mice, as per OECD 420 guidelines. The animals were randomly divided into four groups $(n=8)$. A control group having normal saline solution $(0.9 \%)$ $10 \mathrm{~mL} / \mathrm{kg}$ by oral route was compared with single dose of $2000 \mathrm{mg} / \mathrm{kg}$; p.o. of the three fractions. The animal behavior and mortality index were closely observed for the first $3 \mathrm{~h}$ then at an interval of $4 \mathrm{~h}$ during the next $48 \mathrm{~h}$ ) [48].

\subsection{Measurement of Analgesic Activity}

The analgesic activity was assessed by using an Eddy hot plate method [38] on mice weighing 20-30 g. Mice were placed on the hot plate, which consisted of an electrically heated surface. The temperature of the hot plate was maintained at $55^{\circ} \mathrm{C}$. Responses such as jumping, withdrawal of the paws, and licking of the paws were observed. The time period (latency period) between the placement of the animals on the hot plate, and their responses was recorded. The experimental animals were separated into 5 groups of 8 animals in each group (Group 1: negative control; Group 2: positive control; Group 3: $100 \mathrm{mg} / \mathrm{kg}$ of respective fraction; Group 4: $200 \mathrm{mg} / \mathrm{kg}$ of respective fraction; Group 5: $300 \mathrm{mg} / \mathrm{kg}$ of respective fraction). The respective groups of animals were administered with 100,200 , and $300 \mathrm{mg} / \mathrm{kg}$ of chloroform, ethyl acetate, and $n$-hexane fractions of Kleinia pendula orally and the latency period was recorded at 0, 30, 60, and 120 min after drug administration. Diclofenac sodium $10 \mathrm{mg} / \mathrm{kg}$ was used as a standard drug, and the control group of animals were treated with standard saline.

\subsection{Measurement of Anti-Inflammatory Activity}

Paw edema was introduced by injection of $30 \mu \mathrm{l}$ of $1 \% w / v$ carrageenan suspension on the plantar surface of a hind paw, and the edema was measured using a plethysmometer [49]. The experimental animals were separated into 5 groups of 8 animals in each group (Group 1: negative control; Group 2: positive control; Group 3: $100 \mathrm{mg} / \mathrm{kg}$ of respective fraction; Group 4: $200 \mathrm{mg} / \mathrm{kg}$ of respective fraction; Group 5: $300 \mathrm{mg} / \mathrm{kg}$ of respective fraction. The respective groups of animals were administered with 100,200 , and $300 \mathrm{mg} / \mathrm{kg}$ of chloroform and ethyl acetate fractions of Kleinia pendula orally, and the volume of the paw edema was measured at $0,60,120$, and $180 \mathrm{~min}$ after the drug administration. Diclofenac sodium $10 \mathrm{mg} / \mathrm{kg}$ was used as a standard drug, and the control group of animals was treated with standard saline.

\subsection{Cell Culture}

Human hepatocellular carcinoma cell line (HepG-2), colorectal adenocarcinoma cell line (HCT-116), and breast adenocarcinoma cell line (MCF-7) cells were obtained from the American Type Culture Collection (ATCC). All the cell lines were cultured in RPMI-1640 medium containing penicillin and streptomycin $(100 \mathrm{~g} / \mathrm{mL} ; 100$ units $/ \mathrm{mL})$ and heat-inactivated fetal bovine serum $(10 \% \mathrm{v} / \mathrm{v})$ in a humidified, $5 \%(v / v) \mathrm{CO}_{2}$ atmosphere at $\left.37^{\circ} \mathrm{C}\right)[48]$.

\subsection{Cytotoxicity Studies}

The cytotoxicity of various extract/fractions of Kleinia pendula was tested against human tumor cells using Sulphorhodamine B assay (SRB). Healthy growing cells were cultured in a 96-well tissue culture plate (3000 cells/well) for $24 \mathrm{~h}$ to allow attachment of the cells to the plate. Cells were exposed to the five different concentrations of each extract/fraction $(0.01,0.1,1,10$, and $100 \mu \mathrm{g} / \mathrm{mL})$; untreated cells (control) were added. Triplicate wells were incubated with the different concentrations for $72 \mathrm{~h}$. and subsequently fixed with trichloroacetic acid $(10 \% w / v)$ for $1 \mathrm{~h}$ at $4{ }^{\circ} \mathrm{C}$. After several washing episodes, cells were stained with a $0.4 \%(w / v)$ SRB solution for $10 \mathrm{~min}$ in a dark place. Excess stain was washed with $1 \%(v / v)$ glacial acetic acid. After drying overnight, the SRB-stained cells were dissolved with 
tris- $\mathrm{HCl}$ and the color intensity was measured in a microplate reader at $540 \mathrm{~nm}$. Doxorubicin was used a positive control. The linear relationship between the viability percentage of each tumor cell line and the extracts' concentrations were analyzed to obtain the $\mathrm{IC}_{50}$ (dose of the drug which reduces survival to $50 \%$ ) using SigmaPlot 12.0 software [50].

\subsection{UPLC-PDA-ESI-MS Analysis of the Active Fractions}

Mass spectrometric analysis (UPLC-PDA-ESI-MS) was performed using Waters ACQUITY Xevo Triple quadrupole (TQD) system, which consisted of an ACQUITY UPLC H-Class system and Xevo ${ }^{\mathrm{TM}}$ TQD triple-quadrupole tandem mass spectrometer with an electrospray ionization (ESI) interface (Waters Corp., Milford, MA, USA). Acquity BEH C18 $100 \mathrm{~mm} \times 2.1 \mathrm{~mm}$ column (particle size, $1.7 \mu \mathrm{m}$ ) was used to separate analytes (Waters, Ireland). For the chloroform and hexane fractions, the solvent system consisted of $0.1 \%$ formic acid in water (A) and $0.1 \%$ formic acid in acetonitrile (B) by applying the following mobile phase gradient: 0-4 min, 30\% B; 4-8 min, 35\% B; 8-25 min, 70\% B; 25-30 min, $30 \% \mathrm{~B}$. For the ethyl acetate fraction, the solvent system consisted of $0.1 \%$ formic acid in water (A) and $0.1 \%$ formic acid in acetonitrile (B) with the following mobile phase gradient: $0-4 \mathrm{~min}, 15 \% \mathrm{~B}$; 4-8 $\mathrm{min}, 20 \% \mathrm{~B} ; 8-30 \mathrm{~min}, 55 \% \mathrm{~B} ; 30-35 \mathrm{~min}, 90 \% \mathrm{~B} ; 35-40 \mathrm{~min}, 15 \%$ B. The flow rate was $200 \mu \mathrm{L} / \mathrm{min}$ and the injection volume was $10 \mu \mathrm{L}$. The samples were dissolved in methanol at a concentration of $1 \mathrm{mg} / \mathrm{mL}$ then filtered through a filter of pore size $0.2 \mu \mathrm{m}$. The eluted compounds were detected at mass ranges from 100 to $1000 \mathrm{~m} / \mathrm{z}$. The MS scan was carried out at the following conditions: capillary voltage, $3.5 \mathrm{kV}$; detection at cone voltages, (20-95 V); radio frequency (RF) lens voltage, $2.5 \mathrm{~V}$; source temperature, $150{ }^{\circ} \mathrm{C}$; de-solvation gas temperature, $500{ }^{\circ} \mathrm{C}$. Nitrogen was used as de-solvation and cone gas at a flow rate of 1000 and $20 \mathrm{~L} / \mathrm{h}$, respectively. System operation and data acquisition were controlled using Mass Lynx 4.1 software (Waters).

\subsection{Statistical Methods}

GraphPad Prism software was used for all animal experiments. The values are represented as mean \pm SEM. Statistical analysis for significance $(p<0.05)$ was done using one-way analysis of variance using the Dunnetts posthoc test. SigmaPlot 12.0 software was used for the cytotoxicity assay.

\section{Conclusions}

In conclusion, the present study results show that the n-hexane and chloroform fractions of Kleinia pendula showed significant cytotoxic activity against breast, liver, and colon cancer cell lines, probably due to the fatty acids and terpenoid (tormentic acid). The ethyl acetate and chloroform fractions of Kleinia pendula showed a significant analgesic and anti-inflammatory activities due to phenolic acid content mainly caffeoylquinic acid derivatives, protocatechuic and chlorogenic acids). Therefore, these fractions of Kleinia pendula may be a novel source for the development of new plant-based analgesic, anti-inflammatory, and anticancer drugs.

Author Contributions: M.A., S.E.E., A.S., K.S., H.A. did the cytotoxic activity screening. A.A., K.V., S.A., A.B.M., Y.I.A. did the extraction and fractionation of the plant. N.G. and J.L. did the analgesic and anti-inflammatory screening; H.H. did the LC-MS metabolite determination work. A.A.M. edited the manuscript. All authors have read and agreed to the published version of the manuscript.

Funding: Deanship of Scientific Research at King Khalid University, Research Group Project under grant number (R.G.P.1/119/40).

Acknowledgments: The authors extend their appreciation to the Deanship of Scientific Research at King Khalid University for funding this work through the Research Group Project under grant number (R.G.P.1/119/40).

Conflicts of Interest: The authors declare no conflict of interest. 


\section{References}

1. Newman, D.J.; Cragg, G.M. Natural Products as Sources of New Drugs from 1981 to 2014. J. Nat. Prod. 2016, 79, 629-661. [CrossRef] [PubMed]

2. Harvey, A.L.; Edrada-Ebel, R.; Quinn, R.J. The re-emergence of natural products for drug discovery in the genomics era. Nat. Rev. Drug Discov. 2015, 14, 111-129. [CrossRef] [PubMed]

3. Mothana, R.A.A.; Kriegisch, S.; Harms, M.; Wende, K.; Lindequist, U. Assessment of Yemeni medicinal plants for their in vitro antimicrobial, anticancer and antioxidant activities. Pharm. Biol. 2011, 49, $200-210$. [CrossRef]

4. Halliday, P. Kleinia saginata Compositae. Curtis's Bot. Mag. 1989, 6, 151-156. [CrossRef]

5. Hulin, M. New species and combinations in Kleinia (Asteraceae) from the Horn of Africa. Nord. J. Bot. 2002, 22, 419-426.

6. Halliday, P. The genus Kleinia (Compositae) in Arabia. Kew Bull. 1983, 39, 817-827. [CrossRef]

7. Collenette, S. An Illustrated Guide to the Flowers of Saudi Arabia; Scorpion Publishing Ltd.: London, UK, 1985; p. 220.

8. Migahid, A.M. Flora of Saudi Arabia, 3rd ed.; King Saud University Press: Riyadh, Saudi Arabia, 1988; Volume 2, p. 256.

9. Bohlmann, F.; Knoll, K.H.K. Zwei neue acylpyrrole aus Kleinia kleinioides. Phytochemistry 1978, 17, 599-601. [CrossRef]

10. Bohlmann, F.; Suding, H. Weitere abrotanifolon-derivate aus Kleinia tomentosa. Phytochemistry 1980, 19, 687-688. [CrossRef]

11. Bohlmann, F.; Ahmed, M.; Jakupovic, J.; Jeffrey, C. Sesquiterpenes from Kleinia species. Phytochemistry 1981, 20, 201-251. [CrossRef]

12. Mothana, R.A.; Al-Musayeib, N.M.; Al-Ajmi, M.F.; Cos, P.; Maes, L. Evaluation of the in vitro antiplasmoidal, antileishmanial and antitrypanasomal activity of medicinal plants used in Saudi and Yemeni traditional medicine. Evid. Based Complement. Alternat. Med. 2014, 2014, 905639. [CrossRef]

13. Belayneh, A.; Bussa, N.F. Ethnomedicinal plants used to treat human ailments in the prehistoric place of Harla and Dengego valleys, eastern Ethiopia. J. Ethnobiol. Ethnomed. 2014, 10, 18. [CrossRef] [PubMed]

14. Elmi, A.H.; Farah, M.H.; Fattorusso, E.; Magno, S.; Mayol, L. Volatile Mono and Sesquiterpenoids from Kleinia pendula. Phytochemistry 1987, 26, 3069-3071. [CrossRef]

15. Simirgiotis, M.; Benites, J.; Areche, C.; Sepúlveda, B. Antioxidant capacities and analysis of phenolic compounds in three endemic Nolana species by HPLC-PDA-ESI-MS. Molecules 2015, 20, 11490-11507. [CrossRef]

16. Kang, J.; Price, W.E.; Ashton, J.; Tapsell, L.C.; Johnson, S. Identification and characterization of phenolic compounds in hydromethanolic extracts of sorghum wholegrains by LC-ESI-MSn. Food Chem. 2016, 211, 215-226. [CrossRef] [PubMed]

17. Sun, J.; Liang, F.; Bin, Y.; Li, P.; Duan, C. Screening non-colored phenolics in red wines using liquid chromatography/ultraviolet and mass spectrometry/mass spectrometry libraries. Molecules 2007, 12, 679-693. [CrossRef] [PubMed]

18. Ibrahim, R.M.; El-Halawany, A.M.; Saleh, D.O.; El Naggar, E.M.B.; El-Shabrawy, A.E.R.O.; El-Hawary, S.S. HPLC-DAD-MS/MS profiling of phenolics from Securigera securidaca flowers and its anti-hyperglycemic and anti-hyperlipidemic activities. Rev. Bras. Farmacogn. 2015, 25, 134-141. [CrossRef]

19. Guo, H.; Liu, A.H.; Ye, M.; Yang, M.; Guo, D.A. Characterization of phenolic compounds in the fruits of Forsythia suspensa by high-performance liquid chromatography coupled with electrospray ionization tandem mass spectrometry. Rapid Commun. Mass Spectrom. 2007, 21, 715-729. [CrossRef]

20. Ahmed, R.; Elkhrisy, E.; EL-kashak, W.A.H.; El Raey, M.; Nassar, M.; Aboutabl, E.S.A. Structural Characterization of Polyphenolics in Livistona chinensis Using HPLC-PDA-MS. J. Adv. Pharm. Res. 2019, 3, 23-29. [CrossRef]

21. Catarino, M.D.; Silva, A.M.; Saraiva, S.C.; Sobral, A.J.; Cardoso, S.M. Characterization of phenolic constituents and evaluation of antioxidant properties of leaves and stems of Eriocephalus africanus. Arab. J. Chem. 2018, 11, 62-69. [CrossRef] 
22. Li, F.; Zhang, Y.B.; Wei, X.; Song, C.H.; Qiao, M.Q.; Zhang, H.Y. Metabolic profiling of Shu-Yu capsule in rat serum based on metabolic fingerprinting analysis using HPLC-ESI-MSn. Mol. Med. 2016, 13, 4191-4204. [CrossRef]

23. Li, S.; Lin, Z.; Jiang, H.; Tong, L.; Wang, H.; Chen, S. Rapid identification and assignation of the active ingredients in fufang banbianlian injection using HPLC-DAD-ESI-IT-TOF-MS. J. Chromatogr. Sci. 2016, 54, 1225-1237. [CrossRef] [PubMed]

24. Ben Said, R.; Hamed, A.I.; Mahalel, U.A.; Al-Ayed, A.S.; Kowalczyk, M.; Moldoch, J.; Oleszek, W.; Stochmal, A. Tentative characterization of polyphenolic compounds in the male flowers of Phoenix dactylifera by liquid chromatography coupled with mass spectrometry and DFT. Int. J. Mol. Sci. 2017, 18, 512. [CrossRef] [PubMed]

25. Klausen, K.; Mortensen, A.G.; Laursen, B.; Haselmann, K.F.; Jespersen, B.M.; Fomsgaard, I.S. Phenolic compounds in different barley varieties: Identification by tandem mass spectrometry (QStar) and NMR; quantification by liquid chromatography triple quadrupole-linear ion trap mass spectrometry (Q-Trap). Nat. Prod. Commun. 2010, 5, 407-414. [CrossRef] [PubMed]

26. Sandhu, A.K.; Gu, L. Antioxidant capacity, phenolic content, and profiling of phenolic compounds in the seeds, skin, and pulp of Vitis rotundifolia (muscadine grapes) as determined by HPLC-DAD-ESI-MS n. J. Agric. Food Chem. 2010, 58, 4681-4692. [CrossRef] [PubMed]

27. Ye, M.; Yang, W.Z.; Liu, K.D.; Qiao, X.; Li, B.J.; Cheng, J.; Feng, J.; Guo, D.A.; Zhao, Y.Y. Characterization of flavonoids in Millettia nitida var. hirsutissima by HPLC/DAD/ESI-MSn. J. Pharm. Anal. 2012, 2, 35-42. [CrossRef] [PubMed]

28. Abdel-Hameed, E.S.S.; Bazaid, S.A.; Salman, M.S. Characterization of the phytochemical constituents of Taif rose and its antioxidant and anticancer activities. Biomed. Res. Int. 2013, 2013, 345465. [CrossRef] [PubMed]

29. Negri, G.; Tabach, R. Saponins, tannins and flavonols found in hydroethanolic extract from Periandra dulcis roots. Rev. Bras. Farmacogn. 2013, 23, 851-860. [CrossRef]

30. Xu, L.L.; Guo, F.X.; Chi, S.S.; Wang, Z.J.; Jiang, Y.Y.; Liu, B.; Zhang, J.Y. Rapid screening and identification of diterpenoids in Tinospora sinensis based on high-performance liquid chromatography coupled with linear ion trap-Orbitrap mass spectrometry. Molecules 2017, 22, 912. [CrossRef]

31. Yang, S.T.; Wu, X.; Rui, W.; Guo, J.; Feng, Y.F. UPLC/Q-TOF-MS analysis for identification of hydrophilic phenolics and lipophilic diterpenoids from Radix Salviae Miltiorrhizae. Acta Chromatogr. 2015, 27, 711-728. [CrossRef]

32. Li, P.; Wang, G.J.; Li, J.; Hao, H.P.; Zheng, C.N. Characterization of metabolites of tanshinone IIA in rats by liquid chromatography/tandem mass spectrometry. J. Mass Spectrom. 2006, 41, 670-684. [CrossRef]

33. Han, D.E.; Gao, Z.D.; Zhao, D.; Wang, L.; Li, N.; Li, T.T.; Wu, L.; Chen, X.J. Liquid chromatography mass spectrometry for the determination of salvianolic acid B, a natural compound from the herb Danshen in rat plasma and application to pharmacokinetic study. Biomed. Chromatogr. 2009, 23, 1073-1078. [CrossRef] [PubMed]

34. Li, H.; Yao, W.; Liu, Q.; Xu, J.; Bao, B.; Shan, M.; Cao, Y.; Cheng, F.; Ding, A.; Zhang, L. Application of UHPLC-ESI-Q-TOF-MS to identify multiple constituents in processed products of the herbal medicine Ligustri Lucidi Fructus. Molecules 2017, 22, 689. [CrossRef]

35. Vinodh, G.; Naveen, P.; Venkatesan, C.S.; Rajitha, G.; Shree, A.J. Pharmacological evaluation of abietane diterpenoids from Plectranthus bishopianus as potent antibacterial, antioxidant and their cytotoxic agents. Nat. Prod. J. 2019, 9, 229-237. [CrossRef]

36. Friščić, M.; Bucar, F.; Hazler Pilepić, K. LC-PDA-ESI-MSn analysis of phenolic and iridoid compounds from Globularia spp. J. Mass Spectrom. 2016, 51, 1211-1236. [CrossRef] [PubMed]

37. Münger, L.H.; Boulos, S.; Nyström, L. UPLC-MS/MS based identification of dietary steryl glucosides by investigation of corresponding free sterols. Front. Chem. 2018, 6, 342. [CrossRef] [PubMed]

38. Eddy, N.B.; Leimbach, D. Synthetic analgesics. II, Dithenylbutenyl and dithienylbutylamines. J. Pharmacol. Exp. Ther. 1953, 107, 385-393.

39. Gupta, S.; Singh, A. Antimicrobial, Analgesic and Anti-inflammatory activity reported on Tamarindus indica Linn root extract. Pharmacogn. J. 2017, 9, 410-416. [CrossRef]

40. Ullah, H.M.A.; Zaman, S.; Fatematuj, J.; Akter, L.; Tareq, S.M.; Masum, E.H.; Bhattacharjee, R. Evaluation of antinociceptive, in-vivo \& in-vitro anti-inflammatory activity of ethanolic extract of Curcuma zedoaria rhizome. BMC Complement. Altern. Med. 2014, 14, 346. 
41. Mahmoud, A.M.; Al-Abd, A.M.; Lightfoot, D.A.; El-Shemy, H.A. Anti-cancer characteristics of mevinolin against three different solid tumor cell lines was not solely p53-dependent. J. Enzym. Inhib. Med. Chem. 2012, 27, 673-679. [CrossRef]

42. Shehata, I.A.; El-harshany, E.; Abdallah, H.M.; Esmat, A.; Abdel-sattar, E.A. Anti-inflammatory activity of Kleinia odora. Eur. J. Integr. Med. 2018, 23, 64-69. [CrossRef]

43. Motaal, A.A.; Ezzat, S.M.; Tadros, M.G.; El-Askary, H.I. In vivo anti-inflammatory activity of caffeoylquinic acid derivatives from Solidago virgaurea in rats. Pharm. Biol. 2016, 54, 2864-2870. [CrossRef] [PubMed]

44. Lende, A.B.; Kshirsagar, A.D.; Deshpande, A.D.; Muley, M.M.; Patil, R.R.; Bafna, P.A.; Naik, S.R. Anti-inflammatory and analgesic activity of protocatechuic acid in rats and mice. Inflammopharmacology 2011, 19, 255-263. [CrossRef] [PubMed]

45. Dos Santos, M.D.; Almeida, M.C.; Lopes, N.P.; de Souza, G.E. Evaluation of the anti-inflammatory, analgesic and antipyretic activities of the natural polyphenol chlorogenic acid. Biol. Pharm. Bull. 2006, 29, 2236-2240. [CrossRef] [PubMed]

46. Rayburn, E.R.; Ezell, S.J.; Zhang, R. Anti-Inflammatory agents for cancer therapy. Mol. Cell Pharmacol. 2009, 1, 29-43. [CrossRef] [PubMed]

47. Loizzo, M.R.; Bonesi, M.; Passalacqua, N.G.; Saab, A.; Menichini, F.; Tundis, R. Antiproliferative activities on renal, prostate and melanoma cancer cell lines of Sarcopoterium spinosum aerial parts and its major constituent tormentic acid. Anticancer Agents Med. Chem. 2013, 13, 768-776. [CrossRef] [PubMed]

48. Lorke, D. A new approach to practical acute toxicity testing. Arch. Toxicol. 1983, 54, 275-287. [CrossRef]

49. Winter, C.A.; Risley, E.A.; Nus, G.W. Carrageenan-induced edema in hind paw of the rat as an assay for anti-inflammatory drugs. Proc. Soc. Exp. Biol. 1962, 111, 544-547. [CrossRef]

50. Alahdal, A.M.; Asfour, H.Z.; Ahmed, S.A.; Noor, A.O.; Al-Abd, A.M.; Elfaky, M.A.; Elhady, S.S. Anti-helicobacter, antitubercular and cytotoxic activities of Scalaranes from the Red Sea Sponge Hyrtios erectus. Molecules 2018, 23, 978. [CrossRef]

Sample Availability: Samples of the compounds are not available from the authors.

(C) 2020 by the authors. Licensee MDPI, Basel, Switzerland. This article is an open access article distributed under the terms and conditions of the Creative Commons Attribution (CC BY) license (http://creativecommons.org/licenses/by/4.0/). 